\title{
Adventures in Libraries
}

\author{
Thoughts on Epistemology
}

\author{
Ralph Hanna
}

\begin{abstract}
This essay recounts lessons learned over a career studying medieval manuscripts and the stories of those who made, used, and collected them. Medieval books long outlast their intended or original audiences and have fascinating cultural interactions that extend to the present. What this most pressingly throws up for me is ways of knowing things, and the epistemological value of memory. One needs to store away the little anomalies that one encounters and be prepared for them to surface without bidding in some new context where they might prove generative. If humility might be a first perquisite of scholarly work, certainly memory would be a second. The essay originated as a lecture, delivered remotely in March 2021 for the Renaissance Studies Center at the Newberry Library in Chicago, IL.
\end{abstract}

\section{W} ELl, AS YOU've HEARD, MY TRADE IS KNOWN AS PALAEOGRAPHy. This I understand in a considerably wider sense than merely being a penmanship engineer; as the old joke says, palaeographers are commonly known as people who will date almost anything. My iteration, although I can date many medieval north European scripts and although what I do has made me mainly a library-rat, is the broader 'book-history'. Books are obviously there, in whatever form they take, to communicate texts; as such, they are embedded in communities — of authorship, transmission, and reception. Moreover, medieval books in particular long outlast their intended or original audiences and have fascinating cultural interactions that extend to the present. All this is fun (and may eventually lead to something of interest to someone else), but it's a discovery procedure and what it most pressingly throws up for me is ways of knowing things.

With that in mind, you might look at our first poster-boy, an image of a page from Oxford, Merton College, MS 249 (see Fig 1). For what it's worth (and it's the least of my interests here), this page conveys a piece of a tract written around 1200 to teach preachers how to compose sermons (the hand, another lesser interest, is of c. 1220-1240). More trivial knowledge: the text is by an otherwise unknown Richard of Thetford, it's called 


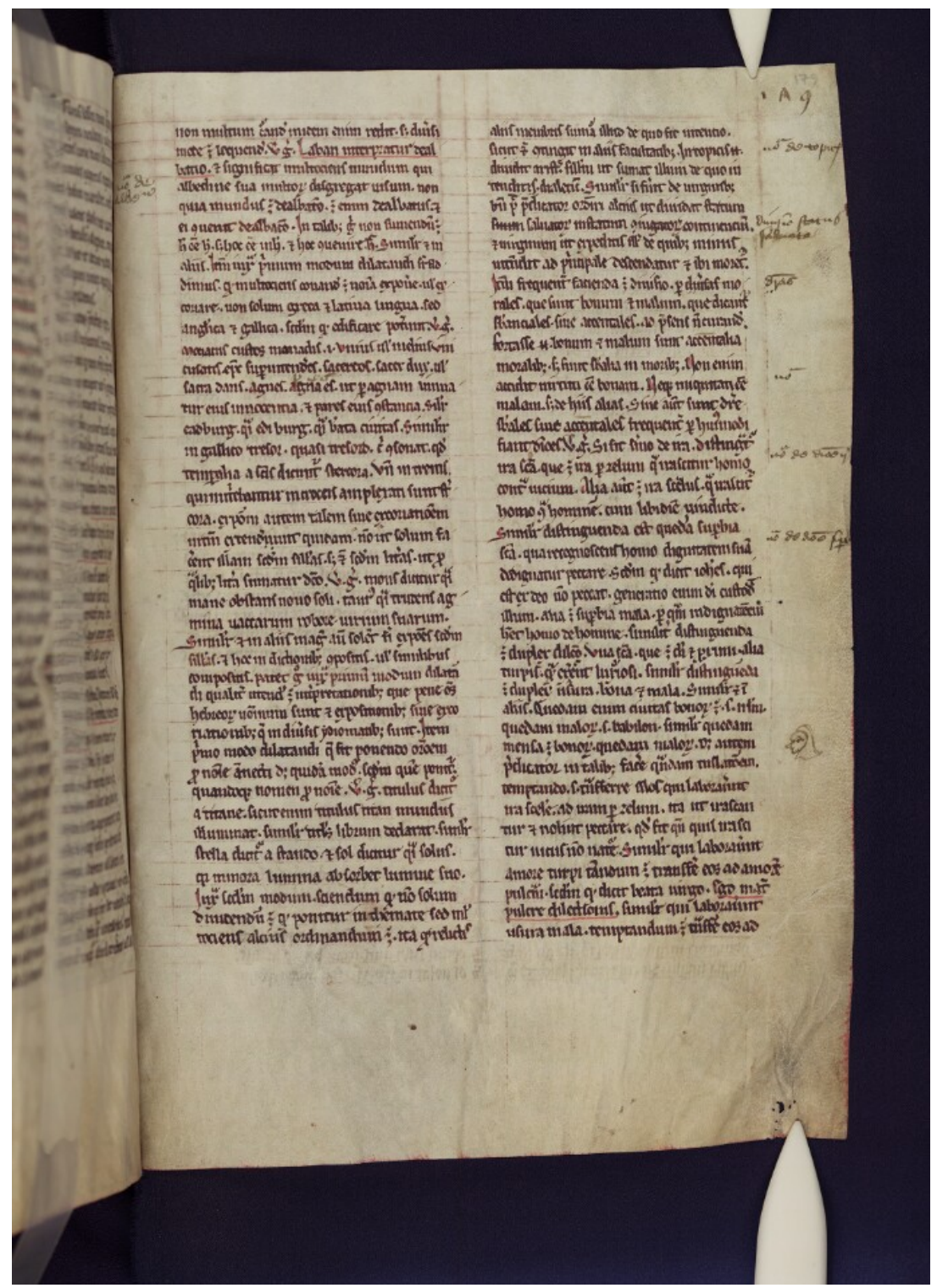

Figure 1. Oxford, Merton College, MS 249, fol. 179r. Image courtesy of the Warden and Fellows of Merton College, Oxford. ${ }^{1}$

1. For a detail of this image, see the cover image of Ralph Hanna's Patient Reading/ Reading Patience: Oxford Essays on Medieval English Literature. Liverpool: Liverpool University Press, 2020. 
'Ars dilatandi sermones' [the art of expanding sermons] and addresses the basic need to develop and exemplify doctrinal points in a way moving and memorable to an audience; for a tract of this type, it had an unusually extensive circulation, about thirty surviving copies all the way to c. 1500 , and a circulation that covered most of western Europe, not just England.

That's what we might call 'old-style-pal'. More important for me is the way I stumbled across this, for stumble I did, and why I treasure this scrap. A text that has engaged me for years and that underwrites much of what I do was written by an Oxford local, the Welshman Walter Map, sometime in the 1160s or 1170s; it's a fake private-letter a fake Valerius sent to a fake recipient, Rufinus, called 'the dissuasion to convince him not to get married'. All this fakery extends to the fiction that the letter was composed late in the first century A.D., and that it's an exchange between two old Roman cronies, wedded to classical authors and to mythology, among other things exchanging literary gossip. It would not be exaggeration to say that every literate European well into the sixteenth century knew this text, or at least pieces of it; while it appears to unearth every conceivable trope of medieval anti-feminism, it wittily exposes all of them as silly. It's a text central to my interests because I'm perpetually fascinated by sober medieval Christians' interest in classical culture, not just texts, citing Seneca or Cicero here and there, but extending to historical minutiae and pagan myth (including such salacious things as Venus's adultery with Mars).

Merton 249 has a pretty old and pretty good text of Map's 'dissuasion'. So, one day in 2013, I thought I would go along and see what I could figure out about its communication to an audience in this copy. In pre-print culture books are always produced for people you know. For what it's worth, I think Merton 249 was originally for Augustinian canons, probably at Coventry or Kenilworth in Shakespeare country, but eventually, after a bout in lay hands not far away in southern Warwickshire in the late thirteenth century, passing through a series of canons of Rochester cathedral in the southeast; one of these Rochester men had mentored a lad who ended up as bishop of Chichester on the south coast, and he, in his turn, gave this, with ninety-nine other books, to Merton in 1374. There's a good deal of stuff for a book-historian to work with here, travels all over southern England, different owners with potentially differing and selective interests, and so forth. But as I pursued my study, I browsed around in the other, not-WalterMap/Valerius texts in Merton 249, just to get some sense of what the people who had originally assembled the book had thought they were doing. And in the process, I quite literally stumbled across what you've got in front of you. 
This passage intrigues me because it is quinti-lingual - implicitly Hebrew and Greek (both presented in Latin), Latin, early Middle English, and early French. I simply give you the last bit of the argument, starting at the end of the sixteenth line in the first column:

Similarly, in French, the word "treasure/tresor" might be interpreted as "very dirty/tres ord". This is appropriate because holy people call worldly goods dung. Thus, Lam 4:5 says "They that were brought up in scarlet have embraced the dung".

Richard offers all this information to demonstrate how the preacher can expand points by offering etymologies for key terms. Now this little discussion appeals to me for deep reasons that have nothing to do with why I was reading Merton 249 in the first place. I grew up in a quadri- or quinti-lingual household (and where and when I grew up, it was far from unusual for people to be multilingually embedded); it's probably one reason why I'm fascinated by medieval England, where trilingualism was obligatory. But it's a situation that complicates and deepens the notion of community and of transmission; among other things, multilingualism is both sustaining and homey while simultaneously exclusionary and estranging.

That's the story behind the image in Figure 1. It does have a modest, but revelatory afterlife. I ended up doing a fair amount of reading around in Richard of Thetford, including the versions of the text in other Oxford manuscripts, and published a little thing about this passage and Richard's general gambit. I've never returned to Walter Map's contribution to Merton 249 (or to Map in this vein generally), maybe a couple of paragraphs in an article about something else entirely. In terms of what I thought I was doing when I trotted off to Merton that morning, the day was pretty much a wash-out. Except, of course, it wasn't: I had found Richard of Thetford and been stimulated into thinking that general public preaching in thirteenth-century (and later) England might have counted on oral comprehension of languages other than English. This, in its turn, raises some very broad questions about textual transmission, that one might be attuned to hearing the language of the text, however it is recorded, as saying something in a language not overtly present.

But there are broader morals to draw here, ones that have nothing to do with the reception of classical culture, or parodic texts, or even the language mixture that had fascinated me, but simply with being human and pursuing knowledge. I went to Merton with a program in mind. I was going to try to find out how Map's 'dissuasion' had worked in one medieval 
context - and I had vague thoughts that this might be something that would extend into 'a project', some kind of extensive view of Map's text and its insertion in various medieval situations. What I found of value, as I see it, was something quite apart from such a project-centredness, entirely serendipitous (I don't think I'd ever heard of Richard of Thetford when I entered the Merton library doors), only adventitiously connected to what I thought I was doing, and only sensible through a kind of lateral leap - it linked up with something else that's valuable to me (as an as yet unindoctrinated child, wanting to know what my parents were saying in Spanish or my great aunts in fractured Galliziener).

I draw from this experience, a pretty typical example of me attempting to do research, several morals, most of them basically having to do with the virtue of humility. First of all, it is all very well to have 'a project', a fixed center for research and a steady eye on what these days is known as 'a research outcome'. But however hard you choose to go at it, you should never let it consume or absorb you. That happens when you keep your eye on 'outcome' - and keep your eye only there. If you determine in advance what your goal is, you will certainly achieve it — and you will achieve only it alone. You're in the position of saying, 'OK, I am now an expert on X. I said I would produce this quantum of X-related material, and now I have done so. Q.E.D... The argumentative gambit of announcing 'a project' and then concluding it simply puts you within a closed circle. And consider all the things outside it you haven't addressed — plate-tectonics or astrophysics, for example — and measure what you might guess about them against what you do know.

Those are not just idle examples. Many basic projects are conceived in such a way as to occlude or render others impossible. Many of you may be involved in one or another form of editorial project, perhaps with ancient languages with reasonably fixed spelling systems. When dealing with vernacular texts, the rules are different; one reports only what are conventionally designated 'substantive variants', those affecting sense. But vernaculars have no fixed spelling and are thus localizable, as written reproductions of spoken dialect forms - in the case of medieval English within about a fifteen-mile radius. Reporting only 'substantives' does illuminate the textual transmission; copies that share the same errors must be linked to one another, since they are drawing on the same exemplar, a physical object that had to travel somewhere. Yet the editorial regimen for vernacular texts entirely obscures the data that would actually localize any copy, since it is suppressed as non-substantive spelling variation - and thus one loses 
exactly that detail from which one might speculate about patrons, their connections, projected use of the book, etc.

Productive things happen either when you interrogate what you think your goal is, or when you are prepared to modify it (because it no longer suits), or when you are distracted from it and have to ask what your distraction means about the goal you originally had. One of the worst enemies to scholarship is a clear sense that you know what you are doing, that you actually control the data, as it were. The great lesson I learned from my undergraduate mentors was not, for example, 'What is Dickens's novel Great Expectations about?' The question they always asked was, bizarrely enough, 'Who are you when you are reading Dickens?' or 'Are you now the same person as you were when you were reading Wuthering Heights last week?' The questions were supposed to make you think about the entire educational project in which you were engaged, how it interfaced with being the person you are (or were or might become), what it exposed about your limitations.

Another question out of the same school, 'How do you know what you don't know?' (The alternative, more biographically keyed version was 'How do you know when you are lost?') The question that follows from that one is, 'If you can know what you don't know, how can you go find it out?, an invitation to something other than a 'project', but rather to an imaginative thought-experiment that would lead you to recognize, not control, some gap/hiatus/lacuna, and to imagine what you would need to know to fill your emptiness, and then to imagine what kinds of helps might exist and where you might have to go to find them. That is how knowledge, both of subject and of self, proceeds.

The answer to queries like this lies in memory. That in many ways tells you who you are now and offers you the clues that tell you where you are or should be going. But it is equally the beginning and guide to all scholarship. First of all, you must remember your ancestors, the scholars who came before you and addressed problems like — as well as tangentially like - those that interest you. Whatever the limitations you see in their work (as a scholar, you should constantly recall that that will be your fate as well), there's always something of value there. The only model I ever had for what I wanted to be was Walter W. Skeat, who passed in 1912. Skeat quite simply knew everything, and in a tactile depth that one cannot match today, because he had read - in many cases, edited - every text and every study available to him. He remains a major figure in the institutionalization of English studies as a university subject. At the same time, 
I feel deeply estranged from Skeat as a person - an ordained Church of England clergyman who never sought or had a pulpit, did not (until he was middle-aged) have a job, and depended on his father-in-law to support him (and an ever-burgeoning offspring, literal, not his many books). Whatever moral opprobrium one might feel about this 'model Victorian gentleman', one says of him (and one can say it of many analogues) what Dante said about Aristotle, that he was 'the teacher of those who seek to know'.

My memory turns out to be rather peculiar, but peculiarly helpful, in what I do. In the main, I remember visual images, something I discovered was unusual only in my mid-twenties. (Until one of my friends pointed this out to me as strange, I thought it was how anyone remembered anything.) As a book-scholar, it's useful, because visual recognition is a large part of what I do; repeated scribal hands or formats of presentation form one way one joins books that seem to have very little in common. Here we might look at the next image, from a manuscript in California; this is a 'pastedown', a wasted leaf fixed over the inner edges of the leather cover, designed to stabilize the binding of a medieval manuscript (see Fig. 2). As frequently occurs, this example recycles a manuscript leaf deemed expendable; for the record, it's from a fourteenth-century copy of the inspirational twelfth-century humanist John of Salisbury's letters.

Now this leaf - although I decry the destruction that led to this form of survival, and although I have handled the book on several occasions, first sometime around 1980 - only resonates for me because of another library experience. I've spent a protracted amount of time studying one central text of Huntington HM 128, the religious vision poem called Piers Plowman, which is the subject of those two scrawls at the foot of the leaf presented here. In one of these bouts, I eventually contributed to an electronic edition of another manuscript of the poem. Now in that book, in Oxford's Bodleian Library, on a blank leaf at the end (see Fig. 3), there's a sixteenth-century inscription, 'Raffe Coppynger Memorandum pat I haue lent to Nicholas brigham the pers ploughman which I borowed of Mr. Le of Addyngton'. In 2002, I looked at this for a while, and had the distinct sense that the hand was familiar. Having a visual memory is all very well, but it doesn't connect the dots; you have to be able to remember where you have seen things before (a kind of memory that note-cards or other filing systems do not stimulate at all). But I could visually recall this as having been at the foot of a leaf (not as in Bodley's Laud misc. 581, near the top) and that it was a re-used leaf. That was enough to get me to haul out the image and ascertain that the first note you see, 'Robert or William Langland made Pers Ploughman', is in the same hand as the Oxford note, that of Sir Ralph 


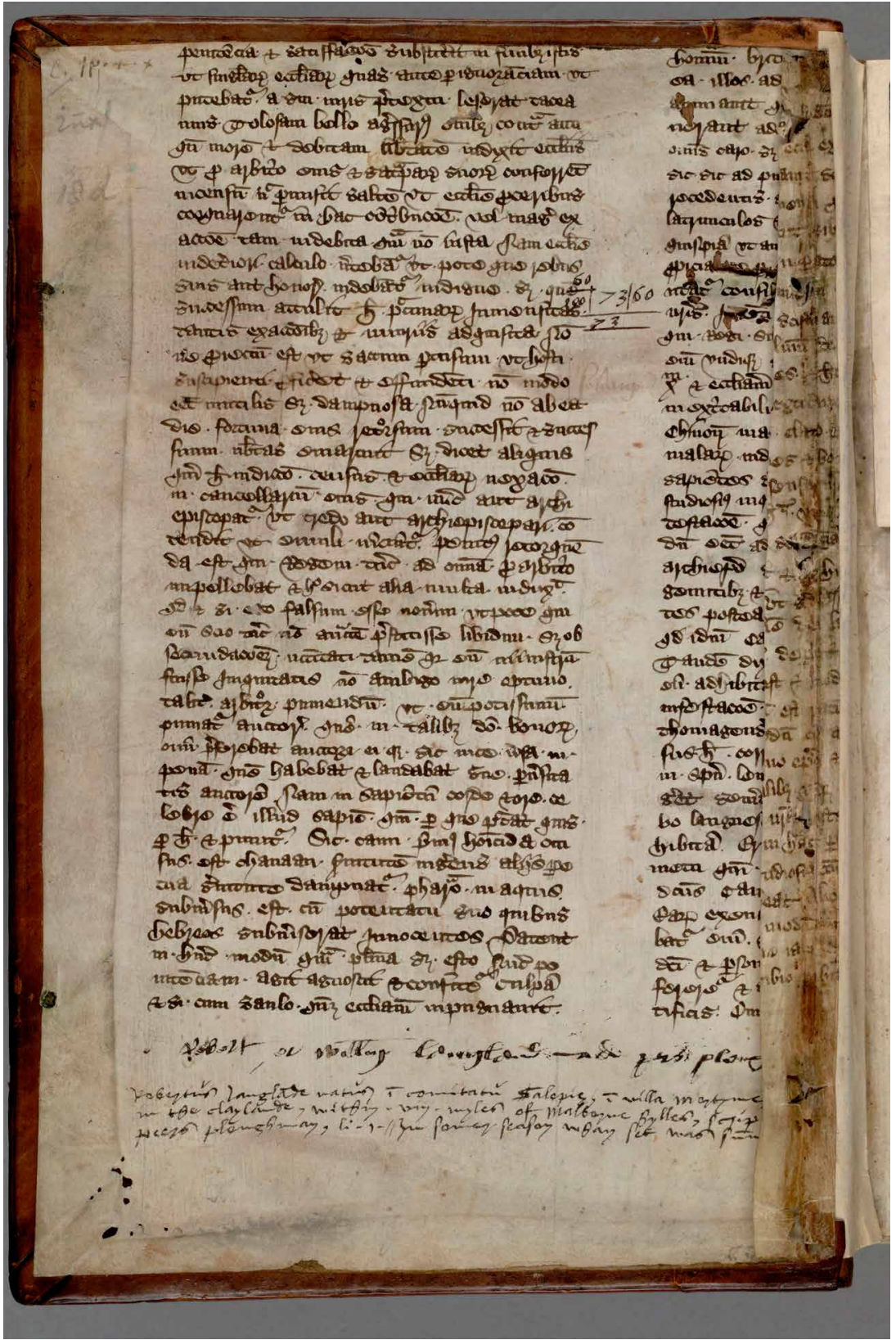

Figure 2. San Marino, The Huntington Library, MS Hm 128, front paste-down. 

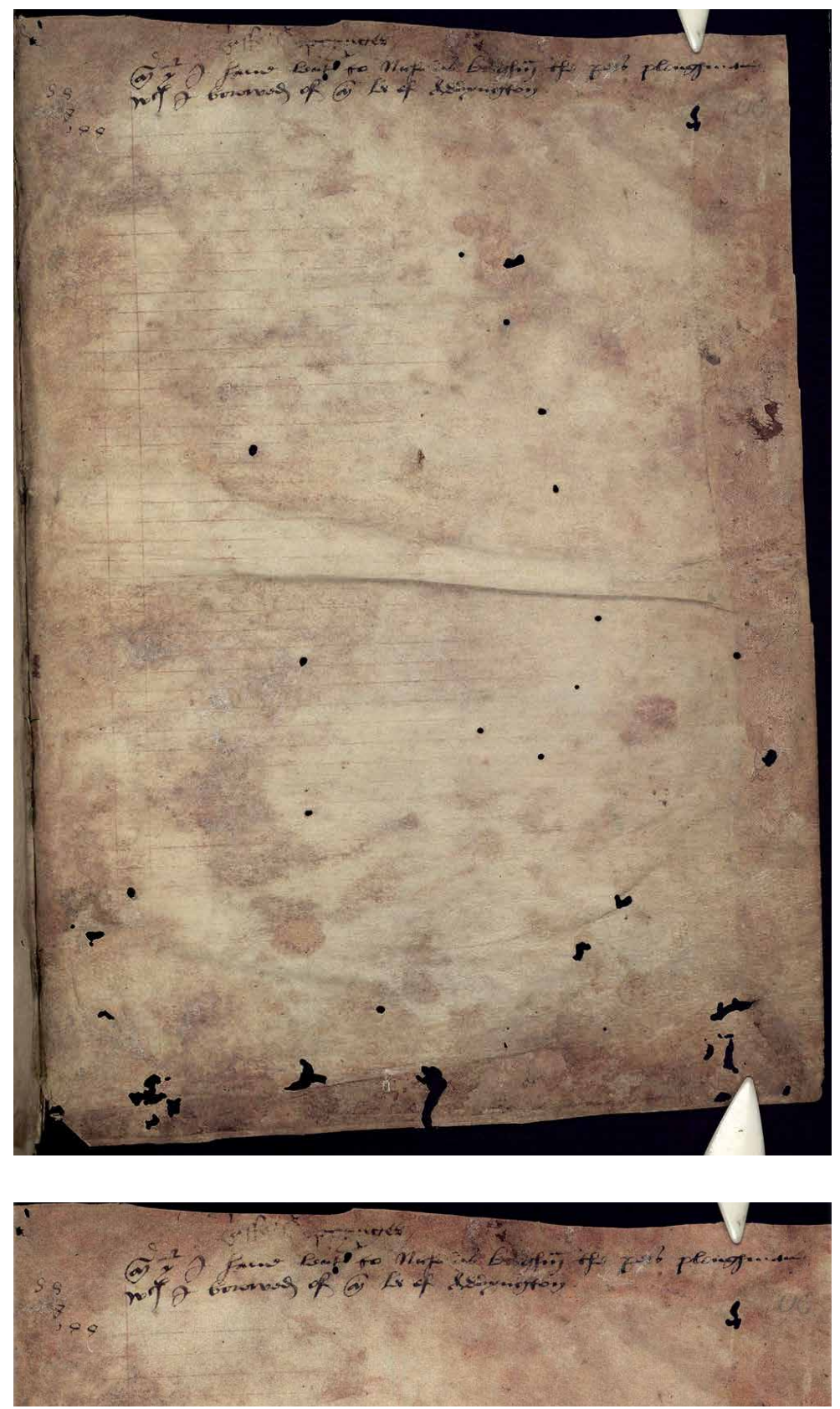

Figure 3. Oxford, Bodleian Library, MS Laud misc. 581, fol. 93r. Image courtesy of the Bodleian Library, University of Oxford and the Piers Plowman Electronic Archive. 
Coppinger of Davington (Kent), who died in 1551. Among the things one learns to do is how to massage various forms of historical archive - here it was the Archbishop of Canterbury's probate records - to identify individuals like this.

Now this would be only what my mother would call a 'nichtsel', something worthless, were it not for the second writing at the foot. That note anyone in my line of work would recognize straight off from the script as the hand of another Skeat-type, a reprehensible individual of inestimable value, John Bale (1495-1563). Bale began life in Roman religious orders, as a Carmelite friar in Norwich in East Anglia, but by the mid-1530s, he had renounced Catholicism, had at least twice been subjected to charges of heresy, married, and become a virulent Protestant flack - mostly of satirical anti-Catholic plays. He was sponsored by and attached to the household of Thomas Cromwell. He, as you will know from Hillary Mantell, if nowhere else, was the person probably singly most responsible, through his suppression of the monasteries, for the first destruction of medieval England.

Bale went on to become an Anglican bishop (of Ossory in Ireland), an exile during Bloody Mary's reign, and died a prebendary of Canterbury Cathedral. But through the 1540s and 1550s, he apparently had second thoughts about what he had conspired to destroy; explicitly as a service to the nation and its unique history, he set about the cataloging and biobibliographical notice of any Englishman who had written in any language. In the process, he visited any library he could find, private as well as the remains of monastic ones. In addition to a formal historical survey, two huge volumes published in Basel, 1557 and 1559, he kept an elaborate notebook that outlines his visits. With his colleague John Leland (who died in 1552), he is a primary source for much of what we know about literary communities of the Middle Ages, particularly Latinate monastic ones.

That also is a 'nichtsel', but for one fact. Bale wrote an entry in his catalogue for William Langland, the author of Piers Plowman. (You will notice he thinks his name was Robert; Coppinger wasn't sure.) Since he is a model of scholarly technique, Bale customarily names his sources; in the case of Langland and his writings, it was Nicholas Brigham - the same person to whom Coppinger had lent a borrowed copy of the poem. It's no accident (as it often is in inscriptions of this type) that the two notes appear together. Coppinger, Brigham, and a more famous individual, William Thynne, who produced the first collected edition of Chaucer in 1532, all worked together in Henry VIII's customs office, and they apparently formed a small coterie of individuals interested in the English past - and in preserving it. They were a group that knew things and had access to books that Bale other- 
wise did not. So there's a small bundle of early antiquaries out there that still await detailed investigation, should anyone want to follow the note I wrote in the online edition of Laud misc. 581. That would lead one much further afield than I needed to go on that occasion - as I've suggested, all scholarship is selective and pointed, never overtly includes the full story. For example: William Thynne, the Chaucer scholar, had a nephew John, another royal servant who built one of the great English stately homes, Longleat House in Wiltshire. John followed his uncle as collector of the past, including at one point having at least handled, if not owned Coppinger's Laud MS; much of his collection is still intact at Longleat, and he was scrupulous enough to produce a still-unpublished catalog of his collection in 1577 .

Those are loose bits that I remember - and chose not to pursue at the time. But if humility might be a first perquisite of scholarly work, certainly memory would be a second. It is the catalyst that makes each of us a person, that binds who we were and who we want to be. It is also, as I have described it above, the key to serendipity, probably the most valuable scholarly tool. No project is ever 'done'; all we publish are interim reports, invariably to be superseded. But just as those writings, what we may charitably hope form 'contributions', are open-ended, so is everything one learns by having produced them. Potentially, there is never waste or dead-end, only wasteful minds. One needs to store it, most particularly to store what made no sense, what couldn't be integrated. Anomaly - usually what one hoped one could get away with ignoring - is the life-breath of innovative thinking. One needs to store it away — and to be prepared for it to surface without bidding in some new context where it might prove generative.

All this requires another grand virtue, patience, and I'll close with an example, in which I got a big boost from one of my Newberry hosts, Ian Cornelius. I once made two rather dispersed trips (2003 and 2008) to a fine and underutilized manuscript library, at Jesus College, Cambridge. On the first occasion, I was investigating a Latin sermon with inserted Middle English in MS 13; on the second, a text of Richard Rolle's English prose psalter that appears fragmentarily on the binding leaves of MS 73. But just as I had done at Merton, and as one must do with any book one handles, in both instances, I did a survey of the whole book as a way of contextualizing what I was looking at. In the process, I found that the same seventeenthcentury individual, one Thomas Man, had signed both books; they were presumably remains from an earlier collection.

That's memory; I did find this vaguely interesting, but not something I was going to pursue. Until, until. A year or two after my second visit 


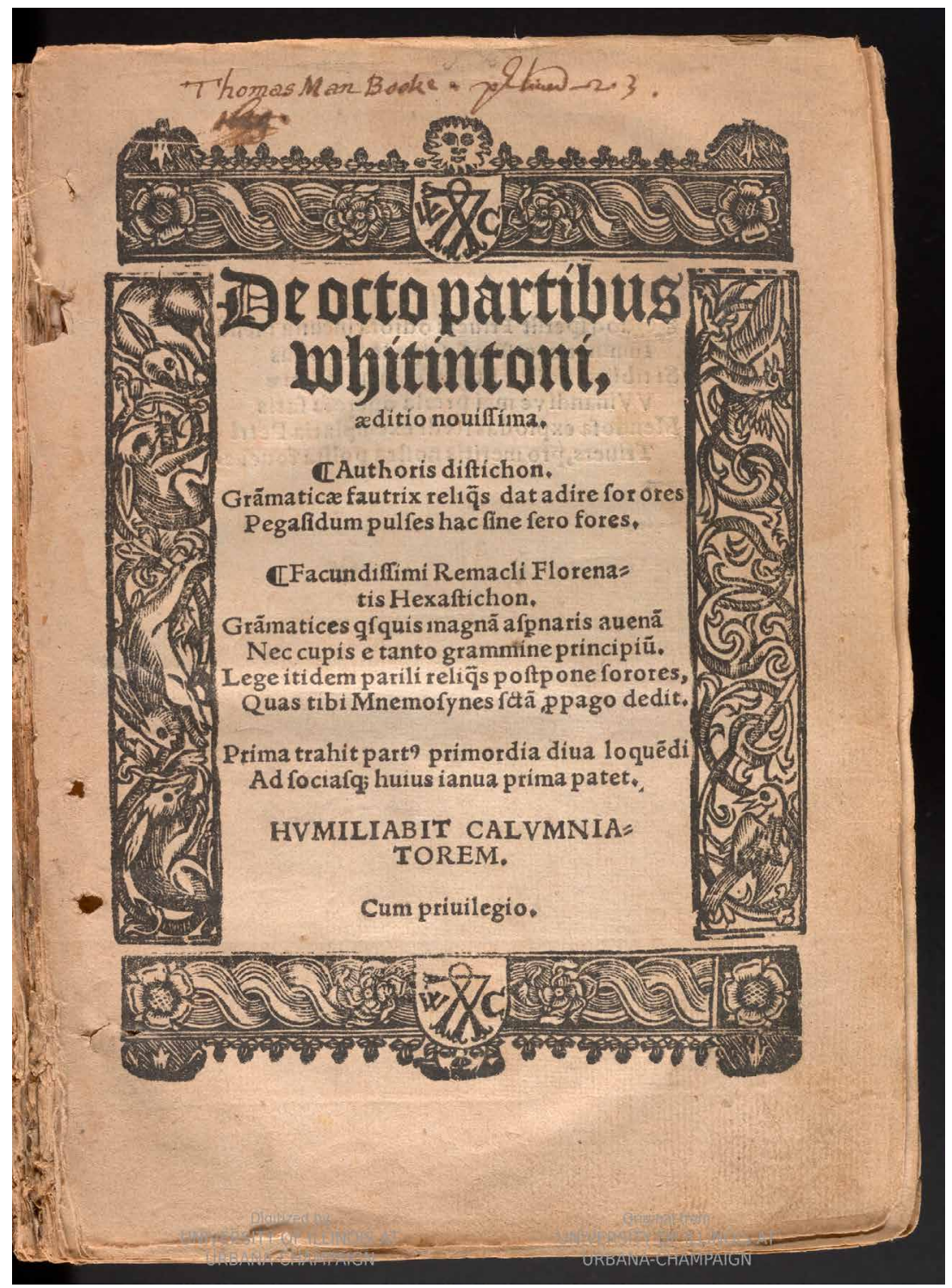

Figure 4. Urbana-Champaign, University of Illinois Library, IU A13079, title page of the first pamphlet. Image courtesy of HathiTrust and the University of Illinois at Urbana-Champaign. https://babel.hathitrust.org/cgi/pt?id=uiuc.5526349. 
to Jesus, my buddy Thorlac Turville-Petre took me to see St Leonard's church in Wollaton, Nottingham. (They own one of the largest surviving fifteenth-century books, a splash antiphoner.) On the wall of the nave, there's a memorial plaque for a Thomas Man, who died in 1690. That set me thinking, and I went back to Jesus, on a protracted errand of patience. By the end of it all - you can read about it in The Library 2020 (notice the gap between when this all started and the date of publication) - I'd gone through all eighty medieval manuscripts at Jesus, as well as all the early printed books, activities probably more trying for the lovely now-departed librarian Frances Willmoth than for me. Nearly fifty of them had been collected by a Thomas Man, a mid-seventeenth-century vicar in North Yorkshire, and had passed to Jesus from his son Thomas, a fellow there and the individual now buried in Wollaton. That was far from the full haul, as the next image, from a printed book of c. 1530 now in Champaign, Illinois, and generously provided by Ian Cornelius, will show (see Fig. 4).

But mysteries remain. For example, what were a group of Catholic recusant farmers in Whitby, c. 1610, doing with Jesus College MS 63, a manuscript with the letters of Poggio Bracciolini, the humanist who discovered Lucretius's De rerum naturae? And - the thought I would leave you with - this whole endeavor was a classic example of what Midwesterners ought to know well, the 'blind pigs find corn' principle. Of the fifty books at issue here, only two in the Jesus collection have any Man signature at all. It is sheer accident that they are the two that, for quite disparate reasons, I initially examined carefully. Only a chain of inferences, predicated on scrutiny of every leaf at Jesus, including those with no text at all, allowed me to reconstruct at a least a substantial part of the Man library. Never despair and never give up.

Keble College, Oxford

\section{Works Cited}

\section{Manuscript and Early Printed Sources}

Cambridge, Jesus College, MS Q.A.13 (James 13)

Cambridge, Jesus College, MS Q.G.26 (James 73)

Oxford, Bodleian Library, MS Laud Misc. 581

Oxford, Merton College, MS 249

San Marino, Huntington Library, MS HM 128

Urbana-Champaign, University of Illinois Library, IU A13079 


\section{Secondary Sourced}

Duggan, Hoyt N., and Ralph Hanna, eds. 2014. The Piers Plowman Electronic Archive, Vol. 4: Oxford, Bodleian Library, Laud Misc. 581 (S.C. 987) (L). SEENET Series A 6. Web edition. The Society for Early English \& Norse Electronic Texts. http://piers.chass.ncsu.edu/texts/L. First published 2004 by Boydell and Brewer as a CD-ROM.

Hanna, Ralph. 2005-2006. "Verses in Sermons Again: The Case of Cambridge, Jesus College, MS Q.A.13”, Studies in Bibliography 57: 63-83.

- 2010. The English Manuscripts of Richard Rolle: A Descriptive Catalogue. Exeter: Exeter University Press.

- 2014. "A Blessed Burgh, Fasting, and Filthy Lucre: Middle English Bits from Merton College, MS 249”. Journal of the Early Book Society 17: 298-306.

- 2020. Patient Reading/Reading Patience: Oxford Essays on Medieval English Literature. Liverpool: Liverpool University Press.

2020. "The Thomas Mans, Their Books, and Jesus College Librarianship". The Library 7th ser. 21.1: 46-73. https://doi.org/10.1093/library/21.1.46. 